\title{
北部九州のマリーナにおける利用状況および 利用者の意識に関する調査結果の分析 ANALYSIS OF QUESTIONNAIRE SURVEY RESULTS ON UTLIZATION STATUS AND VISITORS' PERCEPTION AT MARINAS IN NORTHERN KYUSHU
}

\author{
片山正敏 ${ }^{1}$ \\ Masatoshi KATAYAMA \\ ${ }^{1}$ 正会員 工博 九州共立大学教授 工学部土木工学科（T 807-8585 北九州市八幡西区自由ケ丘 1-8）
}

\begin{abstract}
In planning and designing a marina for a public marine recreation to be involved in waterfront development, it is very important to grasp the significance of the waterfront for the urban residents and reflect it into the environmental consideration by clarifying the prosses of variation in their behavior and perception as visitors to the waterfront.

From the above viewpoint, questionnaire surveys were conducted and analyzed to investigate the utilization status and the visitors' perception at the marinas in Northern Kyushu.

In this paper, the outlines of the questionnaire survey at the seven marinas in Northern Kyushu are described, followed by the detailed results of the questionnaire survey and its multivariate analysis.
\end{abstract}

Key Words : Marina, waterfront development, marine recreation, questionnaire survey, multivariate analysis, Northern Kyushu

\section{1. はじめに}

都市臨海部水辺空間の利用形態の 1 つとして，近 年の海洋性レクリェーションの要請に対応したマリ ーナが挙げられる。マリーナの基本計画設計に関し

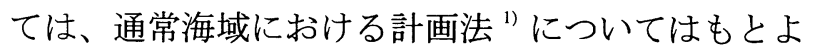
り，寒冷地に建設される場合の設計方法についての 研究 ${ }^{2)}$ もる. また, 基本計画法に関連したマリー ナの係留保管料金に関する一連の研究 ${ }^{3), 4), 55}$ がある.

このようなウォーターフロント開発関連施設の基 本計画設計にあたっては，利用者である都市住民の 水辺空間に対する行動・意識過程を明らかにすると ともに, 都市生活者にとっての水辺の意味を探り, 環境計画などに反映することが大切である.

このため，わが国における政令指定都市の 1 つで ある北九州市内・近郊や福岡市内の 7 つのマリーナ において「アンケート調査」方式により, 来訪者の 利用状況や意識について調査を実施し，その一部に ついては 1 次統計量を中心にすでに報告した。 ${ }^{6), 7), 8)}$

これらの調査では, (1)来訪者の属性・居住地, (2) 来訪目的 - 来訪頻度 - 交通手段, (3)施設の利用状況, (4)施設利用前の意識，(5)施設利用後の意識について
合計 30 項目からなる「アンケート調査」を実施し, 結果を分析した。

本論文では，これら 7 つのマリーナおよびアンケ 一ト調査の概要について簡単に紹介するとともに, アンケート調査結果について 1 次統計量による分析 や多変量解析を実施し, 利用者の行動・意識過程な どについて検討した結果を詳細に述べる。

\section{2. 調査した北部九州のマリーナの概要}

これまでにアンケート調査を実施してきた北部九 州のマリーナは, 図-1 に示すとおり, 北九州市内 ・近郊の新門司マリーナ, 小倉マリーナ, ヨットハ 一バー芦屋ならびに福岡市内の福岡市立ヨットハー バー, マリノア, 福岡マリーナ, 海の中道マリーナ の 7 つマリーナである. また，これらアンケート 調査を行ってきたマリーナの概要 ${ }^{9)}$ を表-1 に示す.

これら 7 つ調査場所において, マリーナおよび 九州共立大学の関係者により, 調査内容 (項目), 要領, 日程などについて事前に打ち合わせを行った.

7 つのマーナでのアンケート調査項目は, 細部 については異なる点もあるが，その概要は表-2 に 
表-1 アンケート調查したマリーナの一覧表 ${ }^{9)}$

\begin{tabular}{|c|c|c|c|c|c|c|c|}
\hline 1. 名 称 & $\begin{array}{l}\text { 新門 司 } \\
\text { マリーナ }\end{array}$ & 小リー倉 & $\begin{array}{l}\text { ヨットハーバー } \\
\text { 芦 屋 }\end{array}$ & 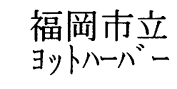 & マリノア & 福リ 岡 & 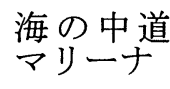 \\
\hline 2. 設立形態 & 第 3 セク & 民間 & 民間 & 公共 & 第 3 セク & 民 間 & 民 間 \\
\hline 3. 設立年 & 1991 年 & 1972 年 & 1973 年 & 1975 年 & 1993 年 & 1973 年 & 1987 年 \\
\hline 4. 所在 地 & $\begin{array}{l}\text { 北九州市 } \\
\text { 門司区 }\end{array}$ & $\begin{array}{l}\text { 北九州市 } \\
\text { 門 司区 }\end{array}$ & $\begin{array}{l}\text { 福岡 県 } \\
\text { 賀 }\end{array}$ & $\begin{array}{c}\text { 福 岡市 } \\
\text { 区 }\end{array}$ & $\begin{array}{c}\text { 福 岡市 } \\
\text { 区 }\end{array}$ & $\begin{array}{c}\text { 福 岡 市 } \\
\text { 区 }\end{array}$ & $\begin{array}{c}\text { 福 岡 市 } \\
\text { 区 }\end{array}$ \\
\hline $\begin{array}{l}\text { 5. 施設規模 } \\
\text { 收容 } \\
\text { 傒施設 }\end{array}$ & $\begin{array}{c}330 \text { 隻 } \\
\text { 陸置ほ加 }\end{array}$ & $\begin{array}{c}150 \text { 隻 } \\
\text { 陸置ほ力 }\end{array}$ & $\begin{array}{r}245 \text { 隻 } \\
\text { 陸置ほか }\end{array}$ & $\begin{array}{r}525 \text { 隻 } \\
\text { 陸置ほ力 }\end{array}$ & $\begin{array}{l}870 \text { 隻 } \\
\text { 陸置ほか }\end{array}$ & $\begin{array}{l}3000 \text { 隻 } \\
\text { 陸 置 }\end{array}$ & 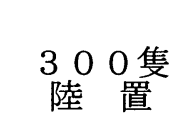 \\
\hline 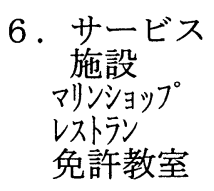 & $\begin{array}{ll}\text { あ } & り \\
\text { あ } & \text { } \\
\text { あ } & \text { り }\end{array}$ & $\begin{array}{ll}\text { な } \\
\text { な } \\
\text { あ } \\
\text { あ }\end{array}$ & $\begin{array}{ll}\text { あ } & り \\
\text { あ } & \eta \\
\text { あ } & \end{array}$ & $\begin{array}{ll}\text { な } \\
\text { あ } \\
\text { あ } \\
\text { り }\end{array}$ & $\begin{array}{ll}\text { あ } & り \\
\text { あ } & り \\
\text { あ } & \text { り }\end{array}$ & $\begin{array}{ll}\text { あ } & り \\
\text { あ } & \eta \\
\text { あ } & \eta\end{array}$ & $\begin{array}{ll}\text { あ } & り \\
\text { あ } & \eta \\
\text { あ } & \end{array}$ \\
\hline
\end{tabular}

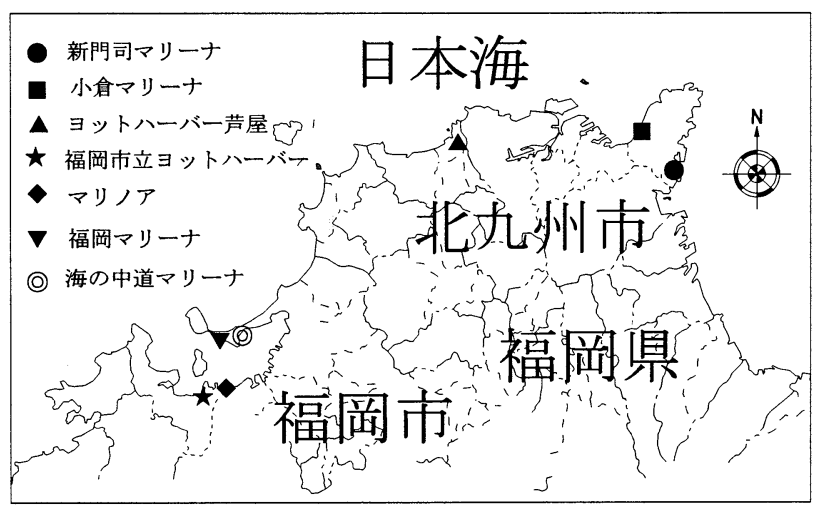

図-1 アンケート調査場所

示すとおりである.

\section{3. 来訪者の属性 · 居住地 \\ （1）来訪者の年齢，性別}

来訪者の年齢は, 小倉マリーナを除いては， 20 歳代が約 $27 \sim 58 \%$ と多数を占め, 続いて 30 歳 代となっており, 夏場のマリンレジャーの特徴が現 れている. (図-2 参照)

また, 来訪者の性別では, 新門司マリーナと福岡 マリーナで女性が男性を少し上回っているが，その 他のマリーナでは男性が女性を上回っており，とく に小倉マリーナでは来訪者の約 $91 \%$ \%が男性となっ ている.

\section{（2）来訪者の職業, 居住地, 区分}

来訪者の職業は，小倉マリーナを除いては，会社 員が約 $40 \sim 84 \%$ と多数を占め, 続いて自営業, 主婦, 学生などとなっている. (図-3 参照)

来訪者の居住地としては, ヨットハーバー芦屋が 郡部であるが北九州市郊外なので市内に準ずるもの
表-2 アンケート調査の概要

\begin{tabular}{|l|l|}
\hline 調査対象 & マリーナへの来訪者全員 \\
\hline 調查期間 & 平成 5 年 7 月 平成 12 年 8 月 \\
\hline 調查方法 & 来訪者全員に調查票を配布・回収 \\
\hline 調査項目 & 大項目 30, 小項目 10 \\
\hline
\end{tabular}

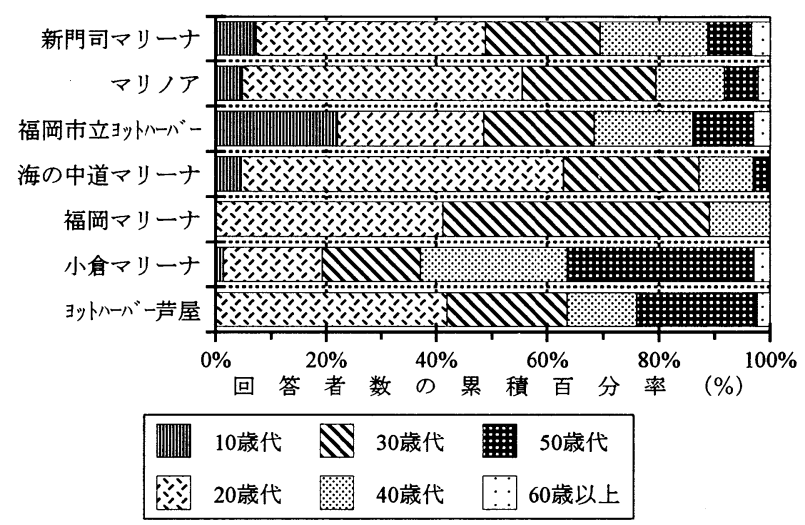

図-2 来訪者の年齢

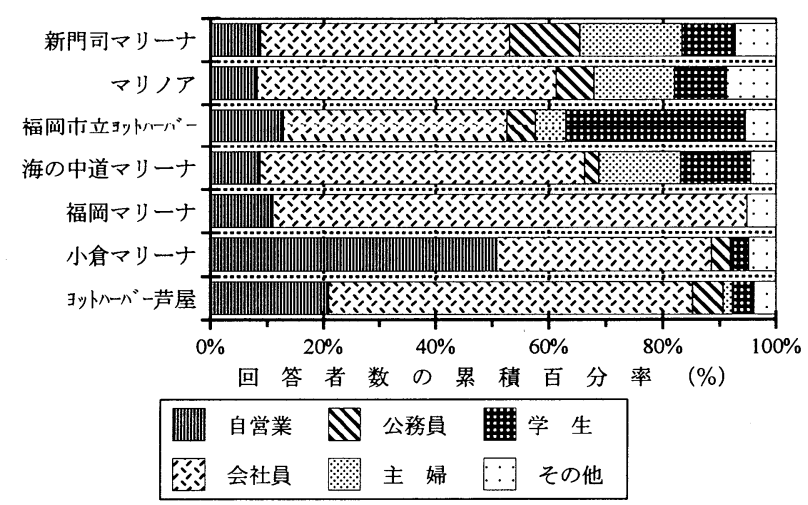

図-3 来訪者の職業 


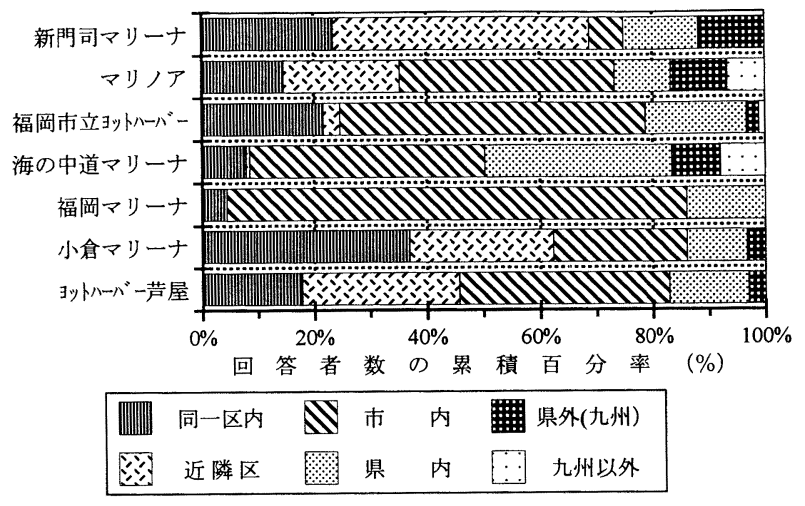

図-4 来訪者の居住地

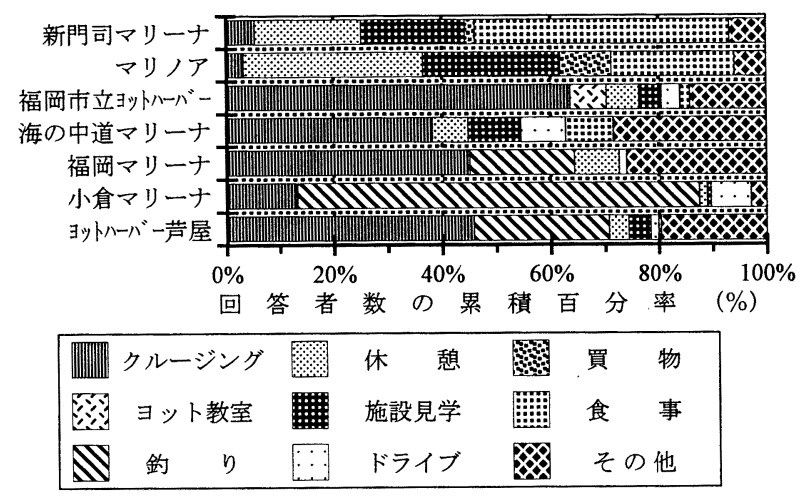

図-5 来訪の目的

とみなして, 地元の区内, 近隣区, その他の市内, 市外のうちの県内，九州内の県外，九州以外として 区分した．いずれのマリーナにおいても，北九州市 内または福岡市内といった比較的近くからの来訪者 が過半数と最も多く, 地域に密着した施設となって いることがわかる.（図-4 参照)

また, 来訪者の区分としては, 新門司マリーナ, マリノアのように 1990 年代に設立された比較的 新しいマリーナでは，一般の来訪者が $90 \%$ 以上と 大多数を占め, 艇置オーナーやクルー（同乗者）は 比較的少ない。また, 福岡市立ヨットハーバー, 海 の中道マリーナ，小倉マリーナでも，一般の来訪者 が比較的多くなっており, 福岡マリーナやヨットハ 一バー芦屋のような 1970 年代に設立された比較 的古いマリーナでは，艇置オーナーやクルー（同乗 者）もかなり多くなっている.

\section{4. 来訪目的 ·来訪頻度 $\cdot$ 交通手段}

\section{（1）来訪の目的，来訪頻度}

来訪の目的についての調查結果を図-5に示す. 来訪の目的について, 統計分析ソフトウェア S P S S ${ }^{10)}$ によ，クラスター分析（Ward 法）を行っ た結果老図-6 に示す.

分析結果によると， 7 つのマリーナは，新門司マ

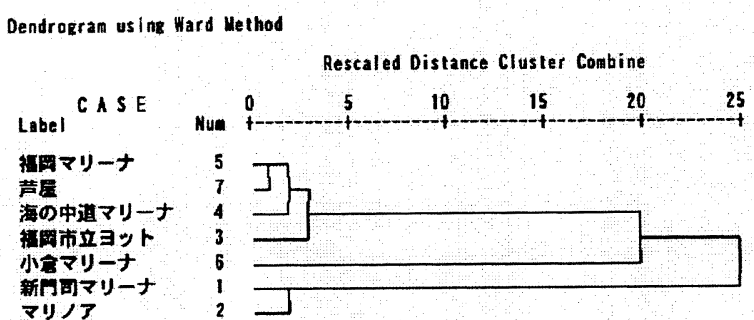

図-6 来訪の目的についてのクラスター分析結果

リーナとマリノアといった 1990 年代に設立され た比較的新しいグループと, 小倉マリーナ, 福岡マ リーナ, ヨットハーバー芦屋, 海の中道マリーナ, 福岡市立ヨットハーバーといったそれ以前の 197 0 年代および 1980 年代に設立された比較的古い

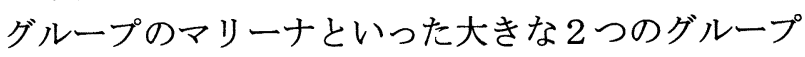
に分類することができる.

比較的新しいグループのマリーナに共通している ことは, クルージングの割合が少なく, 休䕀, 施設 見学, 食事などの割合が多くなっていることである. とくにクルージングが, $10 \%$

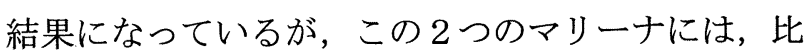
較的規模が大きく, 特色のあるレストランや喫茶店 が付帯的に営業されており, クルージングなど以外 の, いわゆる船を利用しない人達でも十分に楽しむ ことのできるマリーナ施設となっていることがわか る. また, 20 歳台の人達のデートスポットなどと して利用されており，1970年代および 1980 年代に設立された比較的古いグループのマリーナで は, クルージングや釣りの割合が比較的多く，直接 海で行動するという目的を持った利用者が楽しめる 施設となっていることがわかる.

また, 来訪頻度としては, 新門司マリーナ, マリ ノア，海の中道マリーナといった 1980 年代およ び1990 年代に設立されたマリーナでは, 初めて との回答者が比較的多くなっている. これは一般の 来訪者が多いことによるものと思われる.

\section{（2）交通手段，所要時間}

交通手段は，いずれのマリーナにおいても公共交 通機関の利用の便がそれ程よくないこともあって， 自家用車が圧倒的に多くなっている.

また，所要時間については，いずれのマリーナに おいても, 30 分以内, 30 分〜 1 時間といった比 較的短時間との回答が多くなっている.

\section{5. 施設の利用状況}

(1) 利用時の同行者

利用時の同行者（複数回答）は, いずれのマリー 


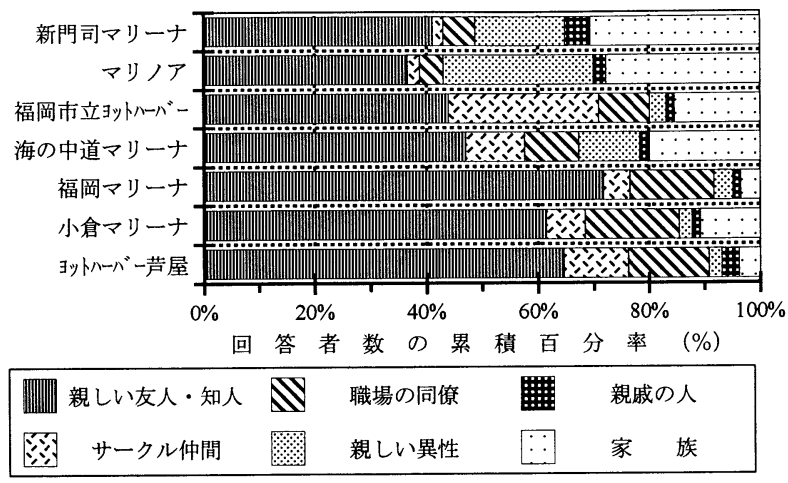

図-7 利用時の同行者

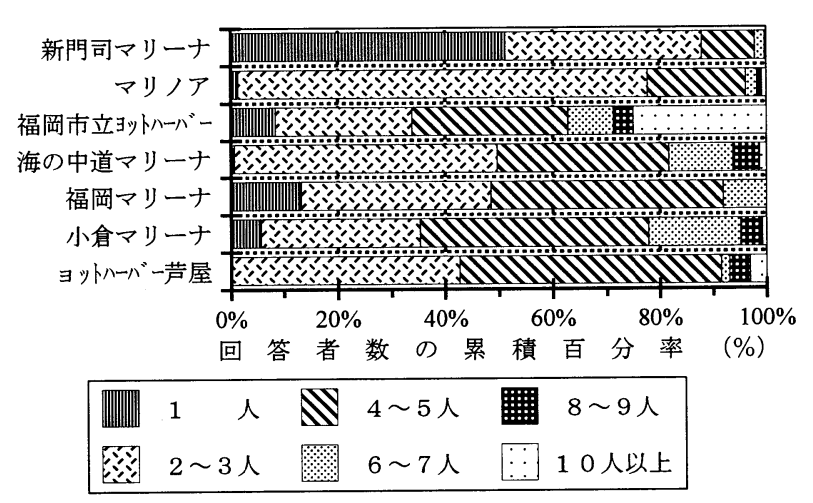

図-8 利用時の人数

ナにおいても親しい友人・知人が約 $37 \sim 72 \%$ と 最も多くなっている. 続いて, 新門司マリーナ, マ リノア，海の中道マリーナといった 1980 年代お よび1990 年代に設立されたマリーナでは, 家族 が約 $20 \sim 31 \%$ と多く, 1970 年代に設立され たマリーナでは, 職場の同僚, サークル仲間などと なっている. (図-7 参照)

\section{（2）利用時の人数, 利用（滞在）時間}

利用時の人数は, マリノア, 海の中道マリーナと いった 1980 年代および 1990 年代に設立され たマリーナでは，2３人で利用するが約 $41 \sim 7$ $6 \%$ と最も多く, 福岡市立ヨットハーバー, 福岡マ リーナ，小倉マリーナ，ヨットハーバー芦屋といっ た 1970 年代に設立されたマリーナでは，4～5 人での利用も多くなっている. (図-8 参照)

また，利用 (滞在) 時間については，新門司マリー ナ, マリノアといった 1990 年代に設立された比 較的新しいマリーナでは，1 時間以内との回答が約 $51 \sim 55 \%$ と最も多く，続いて，1〜3 時間との 回答が約 $38 \sim 44 \%$ となっており，比較的短時間 の利用 (滞在) が多いことがわかる.これに対して, 1970 年代に設立された比較的古いマリーナで は，3〜 5 時間の利用（滞在）も約 $27 \sim 38 \%$ と かなりの回答者となっている.（図-9 参照）

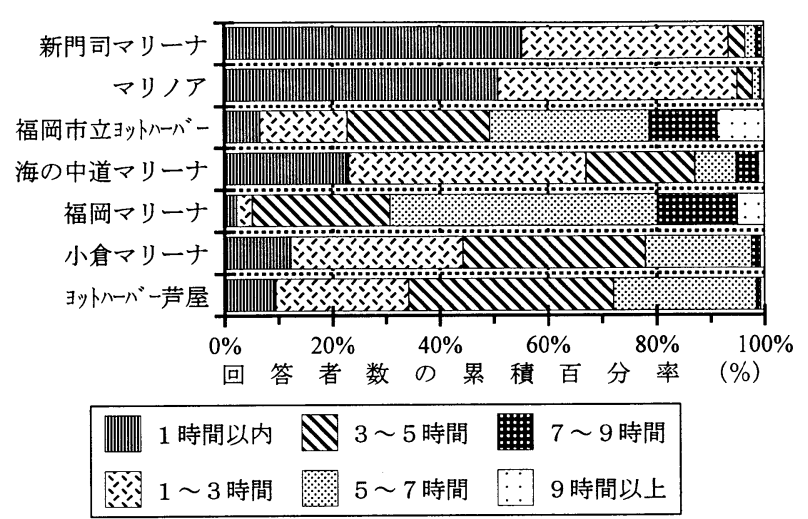

図-9 利用（滞在）時間

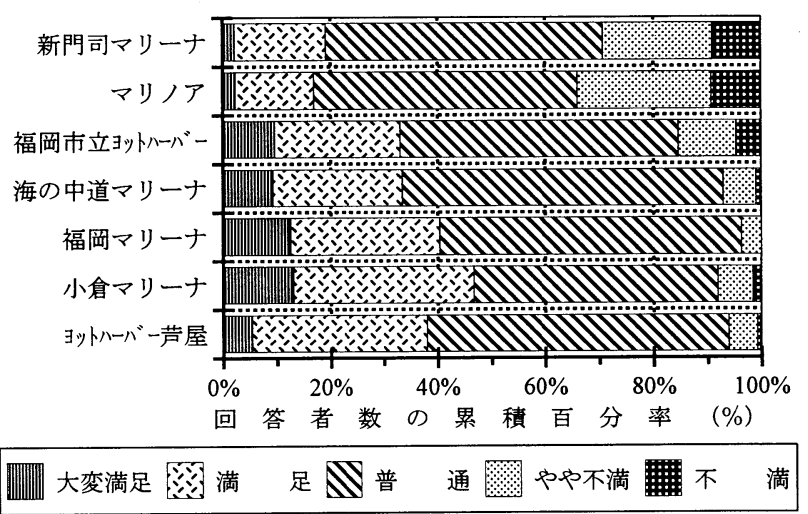

図-10＼cjkstart施設に関する満足度

\section{（3）各種施設の利用状況}

1980 年代および 1990 年代に設立されたマ リーナでは，レストランやマリンショップなどが比 較的よく利用されており，1970 年代に設立され たマリーナでは，ボートの修理施設などもある程度 利用されている.

\section{6. 施設利用前の意識}

\section{（1）現施設についての興味（関心）}

マリーナの現施設（レストラン, ショップなど） についての興味(関心)は，いずれのマリーナも普通 が約 $45 \sim 71 \%$ と最も多く, 続いて, 興味あった が約 14 〜 3 5\%となっており, 各マリーナともに 同様な傾向を示している.

\section{（2）現施設についての知名度}

マリーナの現施設についての知名度は, 各マリー ナともに，よく知られているとまあまあ知られてい るを合わせると約 $50 \sim 76 \%$ となり，比較的知ら れているようである。

\section{7. 施設利用後の意識}

\section{（1）施設に関する満足度}


調査場所の行术 仆

対称的正規化

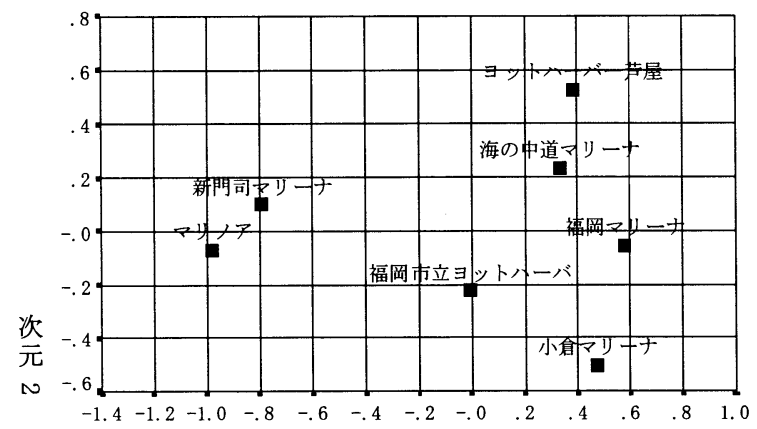

次元 1

満足度の列ポ 仆

対称的正規化

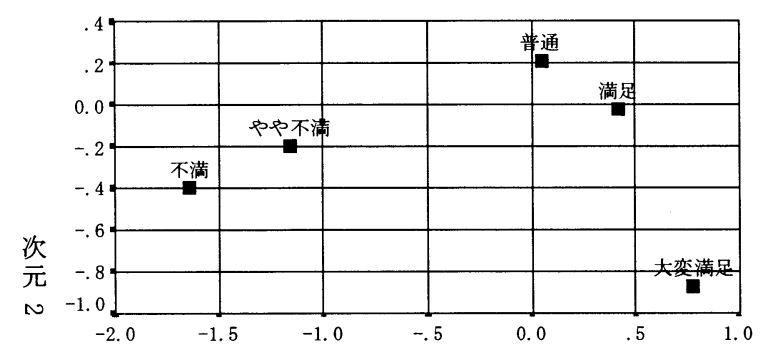

次元 1

図-11 施設に関する満足度についてのコレスポン デンス分析結果

施設（舟艇整備・修理施設，サービス施設など） に関する満足度についての調查結果を図-10 に示 す. 各マリーナともに普通との回答者が約 45 〜 $59 \%$ と多くなっている.

施設 (舟艇整備・修理施設, サービス施設など)

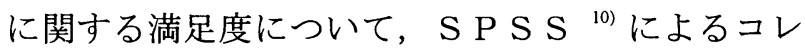
スポンデンス分析の結果を図-11 に示す.

対称的正規化を行った調查場所の行ポイントおよ び満足度の列ポイントより，ヨットハーバー芦屋, 海の中道マリーナ，福岡マリーナ，小倉マリーナと いった 1970 年代および 1980 年代に設立され たマリーナでは, 来訪者は比較的同様な反応を示し, 満足度が比較的高いことがわかる．また，1970 年代に設立された福岡市立ヨットハーバーでは，普 通といった反応を, 新門司マリーナ, マリノアとい った 1990 年代に設立されたマリーナでは，満足 度が比較的低いという反応を示している.

新門司マリーナ，マリノアといった比較的新しい グループのマリーナでの満足度が比較的低いのは, これらのマリーナでは，規模がやや大きくて一般の 利用者も多く, 増設希望施設も水族館 (水槽), 展
調查場所の行ポ イト

対称的正規化

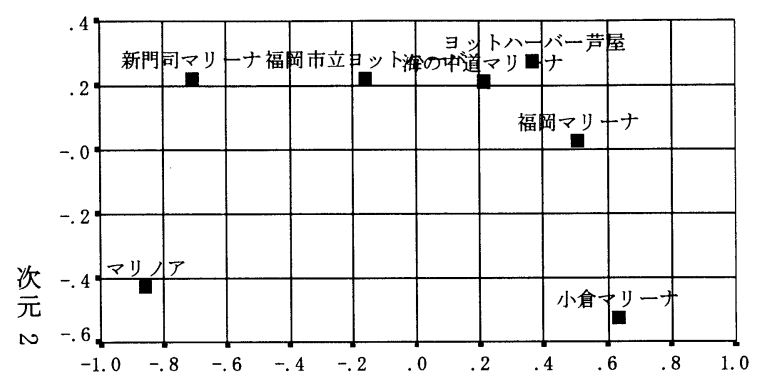

次元 1

イメージの列ポ 仆

対称的正規化

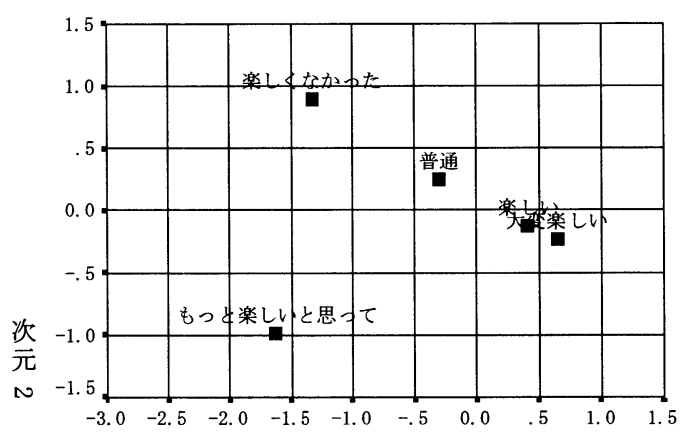

次元 1

図-12 来訪後受けた感じ（イメージ）について のコレスポンデンス分析結果

望台，遊園地，遊歩道など自然環境への期待の多い ものとなっているからであろう.

（2）来訪後受けた感じ（イメージ）

来訪後受けた感じ（イメージ）について，S P S $\mathrm{S}$ によるコレスポンデンス分析の結果を図-12 に示 す.

対称的正規化を行った調查場所の行ポイントおよ びイメージの列ポイントより，小倉マリーナがかな り高くイメージされていることがわかる，福岡マリ 一ナ，ヨットハーバー芦屋, 海の中道マリーナの利 用者はほぼ同じようなイメージを持ち, 高く評価し ていることがわかる．新門司マリーナ，マリノアと いった 1990 年代に設立された比較的新しいマリ 一ナについてはイメージがよくない。

\section{（3）増設を希望する施設}

増設を希望する施設（複数回答）としては，新門 司マリーナ，マリノアといった 1990 年代に設立 された比較的新しいマリーナでは，水族館（水槽）, 展望台などの希望が多い. 福岡市立ヨットハーバー, 


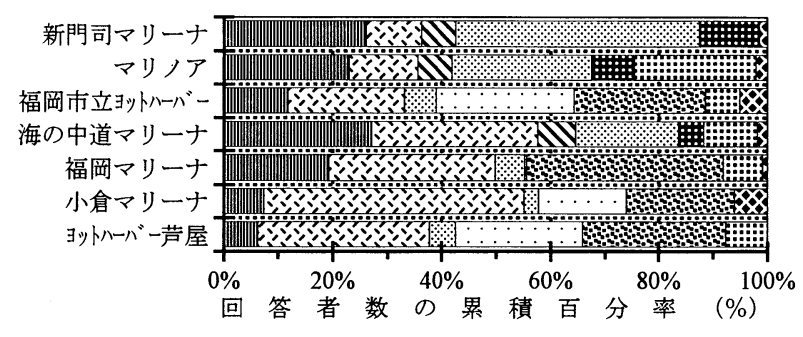

\begin{tabular}{|c|c|c|c|}
\hline 展 望 台 & \% & 水族館・水槽 & マリンショップ \\
\hline 食料品売店 & & 遊 園 地 & 遊歩 道 \\
\hline ゲーム施設 & $\therefore$ & 駐 車 場 & その他 \\
\hline
\end{tabular}

図-13 増設を希望する施設

福岡マリーナ, 小倉マリーナ, ヨットハーバー芦屋 といった 1970 年代に設立された比較的古いマリ 一ナでは, マリンショップ, 食料品売店などの希望 が多いことがわかる．(図-13 参照)

\section{（4）来訪者の要望}

$20 \sim 30$ 歳代の比較的若い来訪者は, レストラ ン, マリンショップ, 駐車場などの充実・整備を, 40 歳代以上の比較的年配の来訪者は, クルージン グ関連の施設などの充実を期待している．また，男 性がマリーナ施設などの充実を期待しているのに対 して, 女性はマリーナ周辺の自然環境 (公園, 緑地, 遊歩道など）の整備も強く期待している.

また, 自営業などの多い艇置オーナーやクルー（同 乗者）は，当然のことながら，クルージング, 釣り のための舟艇の倸留, 保管施設や修理・整備関係の 施設の一層の充害を, 会社員, 主婦などの一般の来 訪者は, レストラン, マリンショップ, 駐車場など の充実・整備や各種イベントの開催などを期待して おり,マリーナを公共施設として必要と感じている。

\section{8. まとめ}

北部九州の 7 つのリーナにおける利用状況およ び利用者の意識についてのアンケート調査結果につ いて, 1 次統計量による分析や多変量解析を実施し て, 利用者の行動・意識過程などについて検討した 結果をまとめると以下のとおりである.

（1）多変量解析結果などによると, 北部九州の $7 つ$ のマリーナは 1970 年代に設立された比較的古い グループ (福岡市立ヨットハーバー, 福岡マリーナ, 小倉マリーナ，ヨットハーバー芦屋）と1990年 代に設立された比較的新しいグループ（新門司マリ 一ナ，マリノア）に大別することができる.また,

1980 年代に設立されたマリーナ（海の中道マリ 一ナ）は，その中間的な状況にある.

(2) 古いグループのマリーナでは, クルージング,
釣りなどの海で行動するといった利用者が比較的多 く, 新しいグループのマリーナでは, 休䕀, 施設見 学, 食事など一般の利用者が比較的多くなっている.

（3）マリーナに増設を希望する施設としては，古い グループのマリーナでは, マリンショップ, 食料品 売店などの希望が多く, 新しいグループのマリーナ では, 水族館（水槽）, 展望台などのほかに遊園地, 遊歩道といった自然環境の整備も希望している.

（4）今後のマリーナの在り方としては, 新しいグル 一プを目途に, 一般の来訪者のためのマリーナ周辺 施設のより一層の充実に力をいれるべきであろう。

謝辞 : 最後に, アンケート調査にあたって御協力い ただいたマリーナの関係者やアンケート調査の実 施, 結果の整理, 分析にあたって御協力いただいた 武田雄君をはじめ, 九州共立大学の関係者 (研究当 時の卒研生の諸君）に感謝いたします。

\section{参考文献}

1) 染谷明夫, 藤森泰明, 森繁泉：マリーナの計画, pp.1-232, 㑣) 鹿島出版会, 1990 .

2) 笹島隆彦, 水野雄三, 寺島貴志, 河合邦弘, 佐伯 浩: 寒冷地に建設されるマリーナの設計方法につ いて,海洋開発論文集, Vol.11，pp.253-257， 1995.

3) 渡会英明 : マリーナの係留保管料金の設定手法に 関する研究, 海洋開発論文集, Vol.10, pp.379384, 1994.

4) 渡会英明 : マリーナの倸留保管料金設定に関する 問題点〜建設原価償還を前提にした場合〜，海洋 開発論文集, Vol.11, pp.259-264, 1995.

5) 渡会英明 : 全国行政区域別におけるマリーナの適 正保管料金設定の試み, 海洋開発論文集, Vol.12, pp. 327-332, 1996.

6)片山正敏 : 都市臨海部の水辺空間における利用状 況および利用者の意識一北九州市の公共マリーナ におけるアンケート調査結果一, 海洋開発論文集, Vol.10, pp.159-164, 1994.

7)片山正敏 : 都市臨海部の水辺空間における利用状 況および利用者の意識一福岡市の民間マリーナに おけるアンケート調査結果一, 海洋開発論文集, Vol.11, pp.247-252, 1995.

8)片山正敏 : 都市臨海部のホテル付帯施設における 利用状況および利用者の意識一マリーナおよびテ ニスコートにおけるアンケート調査結果一, 海洋 開発論文集, Vol.12, pp.321-326, 1996.

9) (社) 日本マリーナ・ビーチ協会 : 新版 全国マリ 一ナガイドブック, pp.452-465, 同協会, 1995 .

10)エス・ピー・エス・エス侏：SPSS Base 10.0J ユーザーズ・ガイド, pp.1-484, 同社, 1999. 